DOI:10.38136/jgon.670061

\title{
Preterm Doğum Yönetiminde Tokolitik Ajanlar ve Kalsiyum Kanal Blokerlerinin (Nifedipin) Yeri
}

\section{The Role Of Tocolytic Agents and Calcium Channel Blockers (Nifedipine) In Preterm Birth Management}

\author{
Seyit Ahmet EROL \\ (1) Orcid ID:0000-0003-0298-9716 \\ Ayșe KIRBAȘ \\ Yaprak ÜSTÜN ENGIN \\ (1) Orcid ID:0000-0001-5184-0008 \\ (1) Orcid ID:0000-0002-3452-2937 \\ ${ }^{1}$ T.C. Sağlık Bakanlığı, Ankara Șehir Hastanesi, Ankara, Türkiye \\ ${ }^{2}$ Medicana International Ankara Hastanesi, Ankara, Türkiye \\ ${ }^{3}$ Sağılık Bilimleri Üniversitesi, Etlik Zübeyde Hanım Kadın Hastalıkları Eğitim ve Araștırma Hastanesi, Ankara, Türkiye
}

\section{öz}

Preterm doğum, neonatal morbidite ve mortalite yönünden önemli bir risk faktörüdür. Kalsiyum kanal blokerleri (nifedipin) preterm doğum medikal tedavisinde kullanımı güvenlidir ve uluslararası kılavuzlarda sık tercih edilen ajanlardan birisidir. Ruhsatlanımı olmaması nedeniyle preterm doğum tedavisinde endikasyon dışı (off-label) kullanıımaktadır. Bu derlemede preterm doğum tedavisinde kullanılan tokolitik ajanlar ve nifedipin ile ilgili güncel literatür sunulmuştur.

Anahtar kelimeler: Preterm doğum, tokoliz, kalsiyum kanal blokerler, nifedipin

\section{GíRiş}

Preterm doğum, perinatal tıpın en önemli sorunlarından biri olarak kalmaya devam etmektedir (1). 2010 yllında yaklaşık 15 milyon prematür infantın dünyaya geldiği ve bu sayının her 10 doğumdan 1 'inden daha fazlasına denk geldiği bildirilmiştir. Preterm doğumların çoğunluğunun (yaklaşık \%60) güney Asya ve sahra altı Afrika ülkelerinde gerçekleştiği gösterilmiştir $(2,3)$. Amerika Birleşik Devletleri'nde (ABD) insidansı yaklaşık olarak $\% 9,6$ 'dır (3).

Tanım olarak 37. gebelik haftasından önce doğum eyleminin başlaması yani düzenli uterin kontraksiyonlara ilerleyici servikal değişikliklerin (servikal silinme ve açılma) eşlik etmesi olan preterm doğum eylemi, düzenli ve ritmik olmayan Braxton Hicks kontraksiyonları ile sıklıkla karışmaktadır (1). Doğum eyleminin 34-36. haftalar arasında gerçekleşmesine geç preterm doğum denir ve tüm preterm doğumların yaklaşık \%71,3'ünü oluşturur. Preterm doğumla doğrudan ilişkili nedenler; membran rüptürü olmaksızın açıklanamayan spontan preterm doğum (\%40-45),

\begin{abstract}
Preterm birth is an important risk factor for neonatal morbidity and mortality. Calcium channel blockers (nifedipine) are safe and these agents are preferred frequently in medical treatment of preterm labor. Due to lack of license, they may use off-label in the treatment of preterm labor. In this review, current literature on tocolytic agents and nifedipine used in the treatment of preterm delivery is presented.
\end{abstract}

Key words: Preterm birth, tocolysis, calcium channel blockers, nifedipine

idiyopatik preterm prematür membran rüptürü (PPROM) (\%30$35)$, maternal veya fetal endikasyon nedeniyle preterm doğumlar (\%30-35) ve çoğul gebeliklerdir $(3,4)$.

Preterm doğum neonatal ölümlerin en sık, ilk 5 yaş çocuk ölümlerinin 2. sık nedenidir (4). 2013 yllında ABD'de 23.446 bebek yaşamın ilk yılında hayatını kaybetmiş, bunların üçte birinde preterm doğum ile ilişkili nedenler gösterilmiştir (5). Doğum haftası küçüldükçe neonatal morbidite ve mortalite gelişme riski tersine artmaktadır (6). Yenidoğan yoğun bakım alanındaki önemli gelişmeler viyabilite sınırını 20-26. haftalara indirmiştir. Yapılan çalışmalarda 22-24. gebelik haftasında doğan bebeklerde sağ kalım \%36, normal nörogelişim ise $\% 20$ saptanmışıı (7). Preterm bebeklerde term bebeklere göre respiratuar distress, bronkopulmoner displazi, intraventriküler kanama, retinopati, sepsis, nekrotizan enterokolit, serebral palsi, pulmoner hipertansiyon gibi kısa ve uzun dönem morbiditelerin görülme sıklığı artar (8). Preterm doğumun yönetimi önemlidir.

Preterm doğum tedavisinde tokoliz 
Preterm doğum eylemini önlemek veya engellemek için çeşitli ilaçlar ve diğer müdahaleler (yatak istirahati, serklaj, pesser uygulamaları vs.) kullanılmasına rağmen, hiçbir tedavi tamamen etkili değildir. Preterm doğum tedavisinde kullanılan başlıca tokolitik ajanlar; beta $(\beta)$ adrenarjik reseptör agonistleri (ritodrin, terbutalin), magnezyum sülfat, non-steroidal antiinflamatuar ilaçlar (prostoglandin inhibitörleri=indometazin), nitrik oksit donörleri, kalsiyum kanal blokerleri (nifedipin) ve oksitosin antagonistleridir (atosiban). Bu ajanlar geçici olarak uterin kontraksiyonu durdurur, hastanın yenidoğan yoğun bakım ünitesi olan ileri merkeze yönlendirilmesi, nöroprotektif magnezyum sülfat tedavisi ve antenatal steroid uygulaması için 48 saate kadar zaman kazandırmaktadır (1). Tokolitik kullanımı için gestasyonel yaş aralığı tartışmalıdır. 34 hafta ve sonrasında, kortikosteroidlerin yaygın kullanılmaması ve bu dönem preterm doğan bebeklerin perinatal sonuçlarının genellikle daha iyi olması nedeniyle pek çok çalışmada 34. gebelik haftasından sonra tokolitiklerin kullanılması önerilmemektedir (9). Tokolitikler uterin kontraksiyonları geçici olarak durdurur, ancak nadiren erken doğumu önler. Yapılan çalışmalarda tokolitik tedavinin plaseboya kıyasla olumsuz sonuç oranlarında inandıııcı bir şekilde azalma sağladığı gösterilememiştir. Akut tedavi sonrası idame tokoliz tedavisi (maintenance tocolysis) genel olarak önerilmemektedir (10).

Kılavuzlarda birinci basamak tokolitik tedavide beta adrenarjik reseptör agonistleri, kalsiyum kanal blokerleri ve non-steroidal antiinflamatuar ilaçlar önerilmektedir $(4,11)$. Preterm doğum tedavisinde kullanılan tokolitik ajanlar Tablo 1'de gösterilmiştir.

Tablo 1: Sık kullanılan tokolitik ajanlar .

\begin{tabular}{|l|l|l|l|}
\hline Ajan & Maternal yan etki & $\begin{array}{l}\text { Fetal, yenidoğan olum- } \\
\text { suz etki }\end{array}$ & Kontrendikasyonlar \\
\hline $\begin{array}{l}\text { Kalsiyum kanal } \\
\text { blokerleri }\end{array}$ & $\begin{array}{l}\text { Baş dönmesi, vücutta } \\
\text { kızarma (flushing) ve hi- } \\
\text { potansiyon; magnezyum } \\
\text { sülfat ile birlikte kullanıl- } \\
\text { dığında kalp hızı, kont- } \\
\text { raktilite ve sol ventriküler } \\
\text { sistolik basınçta azalma } \\
\text { ve hepatik transaminaz- } \\
\text { larda yükselme }\end{array}$ & Bilinen yan etki yok & $\begin{array}{l}\text { Hipotansiyon, aort yet- } \\
\text { mezliği gibi preload ba- } \\
\text { ğımlı kardiyak lezyonlar }\end{array}$ \\
\hline $\begin{array}{l}\text { Non-steroidal anti- } \\
\text { inflamatuar ilaçlar } \\
\text { (indometazin) }\end{array}$ & $\begin{array}{l}\text { Bulantı, kusma özefagial } \\
\text { reflü, gastrit; altta yatan } \\
\text { kanama bozukluğu olma- } \\
\text { yan hastalarda trombosit } \\
\text { disfonksiyonu nadiren } \\
\text { klinik öneme sahiptir. }\end{array}$ & $\begin{array}{l}\text { Intrauterin duktus } \\
\text { arteriosus kapanması*, } \\
\text { oligohidramnios*, } \\
\text { pretermlerde nekrotizan } \\
\text { enterokolit ve } \\
\text { yenidoğanda patent } \\
\text { duktus arteriyozus** }\end{array}$ & $\begin{array}{l}\text { Platelet disfonksiyonu } \\
\text { veya kanama bozukluğu, } \\
\text { hepatik disfonksiyon, } \\
\text { gastrointestinal ülseratif } \\
\text { hastalık, renal disfonk- } \\
\text { siyon, ve astım (aspirin } \\
\text { hipersensitivitesi olan } \\
\text { kadınlarda) }\end{array}$ \\
\hline $\begin{array}{l}\text { Beta adrenarjik } \\
\text { reseptör }\end{array}$ & $\begin{array}{l}\text { Taşikardi, hipotansiyon, } \\
\text { tremor, nefes darlığı, } \\
\text { pulmoner ödem, hipoka- } \\
\text { lemi ve hiperglisemi }\end{array}$ & Fetal taşikardi & $\begin{array}{l}\text { Taşikardi duyarlı mater- } \\
\text { nal kardiyak hastalık ve } \\
\text { kötü kontrollü diyabetes } \\
\text { mellitus }\end{array}$ \\
\hline Magonistleri & $\begin{array}{l}\text { Flushing, terleme, } \\
\text { bulantı, derin tendon } \\
\text { refleklerinde kayıp, } \\
\text { solunum depresyonu ve } \\
\text { kardiyak arrest; kalsi- } \\
\text { yum kanal blokerleri ile } \\
\text { birlikte kullanıldığında } \\
\text { kalp atımı, kontraktilitesi } \\
\text { ve sol ventriküler sistolik } \\
\text { basıncı baskılanımı; ve } \\
\text { nöromuskuler blokaja } \\
\text { neden olur }\end{array}$ & Neonatal depresyon***a & Myastenia gravis \\
\hline
\end{tabular}

* 48 saatten uzun kullanımla ilişkili en büyük risk.

**Bu konudaki veriler celișkilidir.

*** Tek başına fetal nöroproteksiyon için doz ve süre içinde magnezyum sülfat kullanımı kordon kanı magnezyum düzeyleri ile korele olduğunda artmış neonatal depresyon riski ile ilişkili görünmemektedir.
Preterm doğum tedavisinde kullanılan ruhsattı ilaçlar; beta-adrenerjik agonistler (ritodrin, terbutalin, salbutamol), magnezyum sülfat ve oksitosin reseptör antagonistleridir (atosiban). Kalsiyum kanal blokerleri, non-steroidal antiinflamatuar ilaçlar, nitrik oksit donörleri ise preterm doğum tehditi tedavisinde sık kullanılan, güvenli ancak endikasyon dışı (off-label) kullanılan ilaçlardır (1). Tablo 2'de Avrupa ülkeleri ve uluslararası preterm doğum çalısma kılavuzları ve tokolitik tedavi önerileri gösterilmiştir (12).

Tablo 2: Uluslararası preterm doğum kılavuzları ve tokolitik tedavi önerileri.

\begin{tabular}{|c|c|c|}
\hline Ülkeler & Kılavuz ve organizasyonlar & Tedavi \\
\hline İngiltere & $\begin{array}{l}\text { Royal college of obstetricians and } \\
\text { Gynaecologists (RCOG) }\end{array}$ & $\begin{array}{l}\text { Eğer tokolitikler kullanılacaksa, } \\
\text { atosiban veya nifedipin tercih edilir. } \\
\text { Atosiban lisanslıdır, nifedipin değil- } \\
\text { dir. } \beta 2 \text {-agonistleri kullanılmamalıdır. }\end{array}$ \\
\hline Almanya & $\begin{array}{l}\text { German society of gynecologist and } \\
\text { obstetricians (DGGG) }\end{array}$ & $\begin{array}{l}\text { İlk basamak önerisi yok. Atosiban, } \\
\text { fenoterol ve nifedipin eşdeğerdir. } \\
\text { Atosiban daha az yan etkilere } \\
\text { sahiptir. }\end{array}$ \\
\hline Avusturya & $\begin{array}{l}\text { Austrian Society for Gynecology and } \\
\text { Obstetrics (OEGGG) }\end{array}$ & $\begin{array}{l}\text { } \beta \text {-Agonistler veya atosiban. Kesin } \\
\text { hasta grupları için Atosiban ilk tercih }\end{array}$ \\
\hline İsviçre & Ulusal kılavuz yok & Söz konusu değil \\
\hline Belçika & GGOLFB, VVOG & $\begin{array}{l}\text { GGOLFB: Atosiban birinci basamak } \\
\text { tedavisi ( } 48 \text { saat) } 3 \text { kez tekrarlayan } \\
\text { tedavi seçeneğiyle } \\
\text { VVOG: Atosiban tedavisi tercih edilir. }\end{array}$ \\
\hline Hollanda & Dutch Gynecology Society (NVOG) & Atosiban ve nifedipin ilk tercih \\
\hline Fransa & $\begin{array}{l}\text { SPTL rehberi, College National des } \\
\text { Gynecologues et Obstetriciens Fran- } \\
\text { cais (CNGOF) }\end{array}$ & $\begin{array}{l}\text { İlk basamak tedavide atosiban, } \\
\beta 2 \text {-agonistler ve nifedipin. Çoğul } \\
\text { gebeliklerde, ilk basamak atosiban } \\
\text { veya nifedipin }\end{array}$ \\
\hline İtalya & SIGO & $\begin{array}{l}\text { Illk basamak önerisi yok. Ritodrin ve } \\
\text { nifedipin eşdeğerdir. Riskli hasta } \\
\text { için Atosiban ilk tercih }\end{array}$ \\
\hline Norveç & $\begin{array}{l}\text { Norwegian Society of Obstetrics and } \\
\text { Gynaecology (NGF) }\end{array}$ & $\begin{array}{l}\text { 1-atosiban 2-nifedipin } \\
\text { 3-indometazin 4-terbutalin }\end{array}$ \\
\hline Danimarka & $\begin{array}{l}\text { Danish Society of Obstetrics and } \\
\text { Gynecology (DSOG) }\end{array}$ & Atosiban ilk basamak önerilmekte \\
\hline İsveç & Ulusal kılavuz yok & $\begin{array}{l}\text { Seviye III hastane kılavuzlarında } \\
\% 80 \text { 'i ilk basamak atosiban öner- } \\
\text { mektedir. }\end{array}$ \\
\hline İspanya & $\begin{array}{l}\text { SPTL rehberi Spanish Society of } \\
\text { Gynecology and Obstetrics (SEGO) }\end{array}$ & Atosiban ilk seçenek kullanılabilir. \\
\hline Portekiz & Ulusal kılavuz yok & $\begin{array}{l}\text { SPTL rehberi uygulanıyor. Atosiban } \\
\text { veya nifedipin en çok reçete edilen } \\
\text { tokolitik ilaçlardır. Diyabetik has- } \\
\text { talar, çoğul gebelikler ve kardiyak } \\
\text { patolojisi olan kadınlar için Atosiban } \\
\text { tercih edilir. }\end{array}$ \\
\hline
\end{tabular}

GGOLFB: Groupement des Gynécologues Obstétriciens de Langue Française de Belgique; VVOG: Voetbal Vereniging Ons Genoegen; SPTL: spontaneous preterm labor;

SIGO: Società Italiana di Ginecologia e Ostetricia.

\section{$\beta$-Adrenerjik Reseptör Agonistleri}

Pek çok bileşen, intraselüler iyonize kalsiyum seviyelerini azaltmak ve miyometriyal kontraktil proteinlerinin aktivasyonunu önlemek için $\beta$-adrenerjik reseptörlerle reaksiyona girer. Bu ajanlar, $\beta$ reseptörlerinin uyarılması yoluyla bronş ağacında, kan damarlarında ve miyometriyumda düz kasları gevşetmeye yarar. $\beta$-reseptörler $\beta 1$ ve $\beta 2$ alt tiplere ayrımıştı. $\beta 1$ reseptörleri büyük ölçüde kardiyak etkilerden sorumludur ve $\beta 2$ reseptörleri düz kas relaksasyonuna, hepatik glikojen üretimine ve insülinin 
adacık hücresinden salımına aracııık eder. Dokularda değişken oranlarda $\beta 2-\beta 1$ reseptörleri bulunmaktadır. Kalp, vasküler sistem ve karaciğerdeki $\beta 1$ reseptörlerinin uyarıması, bu ilaçların yan etkilerini açıklar (3). ABD'de $\beta$-mimetik ilaçlardan, ritodrin ve terbutalin obstetride kullanılmakla birlikte, sadece ritodrin Amerikan Gıda ve Illaç Dairesi (FDA) tarafından preterm doğum için onaylanmışıı. Ritodrin 2003 yııında ABD pazarından gönüllü olarak geri çekilmiştir. Preterm doğum tehditi nedeniyle ritodrin tedavisi sonrası yenidoğanlarda preterm doğum oranları ve komplikasyonlarının daha düşük olduğunu bildiren randomize çalışmalar olmakla birlikte intravenöz (iv) ritodrinin doğumu 24-48 saat süre geciktirmesi dışında ilave faydası gösterilemeyen randomize çalışmalarda mevcuttur (4). $\beta$-agonist ajanlar sodyum $(\mathrm{Na})$ ve su tutulumuna, volüm yüklenmesine, pulmoner ödem gibi ciddi hatta ölümcül maternal yan etkilere sahiptir. Ayrıca artmış kapiller permeabilite, kardiyak ritim bozuklukları ve miyokard iskemisi ile de ilişkisi gösterilmiştir. Terbutalin, ABD'de erken doğumu önlemek için yaygın olarak kullanılmaktadır. Ritodrin gibi akciğer ödemine neden olabilir. Düşük doz terbutalin, subkutan pompa ile uzun süreli uygulanabilmekle beraber randomize çalışmalarda tedavide ilave fayda gösterilememiştir. Preterm doğum tehditinde oral terbutalinin tokoliz etkisi yoktur (4). 24-34 hafta arası preterm doğum tehditi olan 203 kadında yapılan randomize bir çalışmada, her 4 saatte 5 $\mathrm{mg}$ oral terbutalin verilen grup ile plasebo grup arasında 1 hafta içinde doğum oranları, medyan latent süre, doğumda ortalama gestasyonel yaş ve preterm doğum nüks insidansı açısından her iki grupta sonuçlar benzer bulunmuştur (13). $\beta$-agonist ajanlar tedavi sırasında geçici hiperglisemi ve hipokalemiye neden olabilmektedir. Yine tedavi sonrası neonatal hipoglisemi, hipokalsemi ve ileus görülebilir ve bu durum özellikle maternal infüzyon doğumdan en az 2 saat önce kesilmezse klinik olarak anlamlı olabilir (3).

Ciddi maternal ve fetal yan etkileri nedeniyle FDA 2011 yılında preterm doğum eylemi tedavisinde terbutalin kullanımına ilişkin bir uyarı yayınlamıştır (4). Amerikan Obstetrisyen ve Jinekologlar Derneği (=ACOG), terbutalinin tokolitik veya uterin taşisistolünün akut tedavisi olarak sadece kısa süreli hospitalize şeklinde kullanımını önermektedir (1). Yaygın kullanım protokolü, 3-5 dakikada (dk) hızlı etkili olduğu 4 saatte (st) bir 0.25 $\mathrm{mg}$ subkutan şeklindedir. Ayrıca klinik pratikte eksternal sefalik versiyon öncesinde tokolitik olarak kullanılmaktadır (3).

Magnezyum sülfat

Yeterli yüksek konsantrasyonda iyonize magnezyum miyometriyal kontraktiliteyi değiştirebilir. Magnezyum bir kalsiyum an- tagonistidir ve farmakolojik dozlarda verildiğinde travayı inhibe edebilir. Maternal serum magnezyum seviyeleri 5 ile $8 \mathrm{mg} / \mathrm{dl}$ olduğunda miyometriyal kontraktilite inhibe edilir. Tokolotik amaçI intravenöz magnezyum sülfat, $4 \mathrm{~g}$ yükleme dozu olarak verilir ve ardından $2 \mathrm{~g} / \mathrm{saat}$ infüzyon olarak idame yapılır. $\beta$-mimetik ajanlar gibi magnezyum tedavisi de daha nadir olmakla birlikte pulmoner ödeme neden olabilir (3). Magnezyum sülfat ile tokolizin değerlendirildiği randomize çalışmalarda Cotton ve ark. preterm doğum yapan 54 kadında magnezyum sülfat, ritodrin ve plaseboyu karşılaştırmış ve sonuçlarda çok az farklılık tespit etmişlerdir (14). Cox ve ark.156 kadına magnezyum sülfat veya normal salin infüzyonu vermiş, magnezyum sülfat ile tedavi edilen kadınlarda ve yenidoğanlarda plasebo verilenlere kıyasla benzer sonuçlar bildirilmiştir (15). Crowther ve ark. magnezyum sülfatın tokolitik bir ajan olduğunu gözden geçirmiş, etkisiz ve potansiyel olarak zararlı olduğu sonucuna varmışlardır (16). Son olarak FDA, 5-7 günden fazla maruz kalan fetüslerde kemik incelmesi ve kırıkları nedeniyle preterm doğum eylemini durdurmak için verilen magnezyum sülfatın uzun süre kullanılmasının fetüste düşük kalsiyum seviyeleri riski nedeniyle uyarıda bulunmuştur. Günümüzde yeterince etkin olmaması, alternatif daha etkin ajanların varlığı ve olası potansiyel zararlı nedeniyle magnezyum sülfat tokolizi pek çok klinikte terk edilmiştir (17).

\section{Prostaglandin (Siklooksijenaz) İnhibitörleri}

Prostaglandin sentezi, siklooksijenaz enziminin (COX) non-steroid antiinflamatuar ilaçlar (NSAID) tarafından inhibe edilmesiyle azaltılır. Prostaglandinler, uterus kas kontraksiyonu son basamağına aracılık ederek miyometriyal hücrelerde serbest hücre içi kalsiyum seviyelerinde artışa ve miyozin hafif zincir kinazın aktivasyonunda artışa neden olur. Gap junction formasyonu prostaglandinler tarafından artııılır. En sık kullanılan NSAID tokolitik olan indometasin plasentadan rahatça geçer. Aspirinin aksine, indometasin geri dönüşümlü olarak COX'a bağlanır, böylece inhibisyon sadece ilaç atılana kadar sürer. Umbilikal arter serum konsantrasyonu oral uygulamadan sonraki 6 saat içinde maternal seviyeye eşitlenir. Yarılanma ömrü maternal 4-5 saat, full term infantta 15 saat, preterm infantta ise anlamlı olarak daha uzundur (3). Indometazinin uterin kontraksiyonları durdurabileceği, preterm doğumu geciktirmede etkin olabileceği ve tokolitik olarak kullanılabileceğine dair çalışmalar mevcuttur. Bununla birlikte, Morales ve ark. preterm doğum yönetiminde indometazinin, ritodrin ve magnezyum sülfata göre etkinliklerinin kıyaslandığı çalışmasında gruplar arası anlamlı fark saptanmamıştır (18). Berghella ve ark. sonografik olarak 
kısa serviksli kadınlara verilen dört indometasin çalışmasını gözden geçirdikleri derlemesinde, indometazin tedavisinin bu olgularda etkisiz olduğunu vurgulamıştır (19).

Indometasin oral iyi absorbe olur, ancak rektal olarakta uygulanabilir. Standart rejim olarak $50 \mathrm{mg}$ oral yükleme dozu ve ardından her 6 saatte bir oral 25 ile 50 mg idame dozu şeklindedir (3). Terapötik dozda oligohidramnios riski nedeniyle kullanımı 32 hafta öncesi gebelerde 24 ile 48 saat arasında sınırıdır. Amniyotik sıvı takibi ile bu durum erken tespit edilebilir ve ilacın kesilmesiyle oligohidroamnios geri dönüşümlüdür (4). Norton ve ark. 30 haftadan önce doğan ve preterm doğum tehditi nedeniyle indometazin maruziyeti olan yenidoğanlarda nekrotizan enterokolit (NEK) görülme sıklığı \%30, kontrol grubunda ise $\% 8$ olarak belirtilmiştir. Ayrıca intraventriküler kanama (IVK) ve patent duktus arteriozus (PDA) insidansı indometazin grubunda daha yüksek tespit edilmiştir (20). Ancak indometazin kullanımıyla IVK, NEK, PDA, sepsis ve neonatal ölüm arasında herhangi bir ilişki tespit edilemeyen klinik çalışmalar bulunmakta birlikte aralarındaki ilişki tam aydınlatılamamıştır. Yine metaanalizlerde antenatal indometazin kullanımının neonatal sonuçları yönünden çelişkili sonuçlar sunulmuştur (21).

Güncel pratikte, tedavi kılavuzlarına dikkatle uyulduğunda komplikasyonlar nadir görülür. Başlıca fetal yan etkiler duktal vazodilatasyonu sürdüren prostasiklin ve PGE2 oluşumunun indometazin tarafından inhibe edilmesi nedeniyle duktus arteriyozusun erken konstrüksiyonu, oligohidramnios ve neonatal pulmoner hipertansiyondur (3). Reinebrant ve ark. 20 çalışmanın gözden geçirildiği derlemesinde, plasebo ya da herhangi bir diğer tokolitik ajan ile karşılaştııılı̆ğında, indometazin dahil siklooksijenaz inhibitörlerinin net bir fayda sağlamadığını belirtmişlerdir (22).

\section{Nitrik oksit (NO) donörleri}

Düz kas hücrelerindeki siklik guanozin monofosfat (cGMP) içeriğindeki artış, düz kas gevşemesine neden olan miyozin hafif zincir kinazını aktive eder. Nitrogliserin gibi NO donörleri spontan oksitosin ve prostaglandin ilişkili aktiviteyi inhibe eder. Güçlü düz kas gevşeticileridir ve etkileri vasküler yatak, bağırsak ve uterus üzerinedir. Baş ağrısı ve maternal hipotansiyon sık görülen yan etkidir (3). Randomize klinik çalışmalarda, oral, transdermal veya intravenöz olarak uygulanan nitrogliserinin diğer tokolitiklere göre etki yönünden herhangi bir üstünlüğü gösterilememiştir (23).

Atosiban

Oksitosin, sarkoplazmik retikulumdaki bir proteine bağlanan ve sitoplazmaya kalsiyum salınmasına neden olan fosfatidilinositolün inositol trifosfata dönüştürülmesini indükleyerek doğumdaki kasılmaları uyarır. Oksitosin reseptör antagonistleri (ORA), kalsiyum salınımını önlemek veya azaltmak, miyometriyum ve desiduadaki reseptörlere bağlanmak için oksitosin ile yarışır. Oksitosin reseptör antagonisti atosiban, spontan ve oksitosin ilişkili kontraksiyonları inhibe eder, ancak prostaglandin ilişkili kontraksiyonlara etkisizdir (3). Nonapeptid oksitosin analogu olan bir ORA'dır. Maternal yan etkiler nadirdir, çünkü oksitosin reseptörleri sadece uterus ve memede bulunmaktadır. Oksitosin antagonistleri plasentayı geçebilmekle beraber genel olarak fetal kardiyovasküler sistemi veya asit-baz dengesini etkilemediği gösterilmiştir. Atosibanın neonatal sonuçları iyileştirmediği ve anlamlı neonatal morbidite ilişkisi randomize klinik çalışmalarda gösterilmiştir (24). Avrupa'da yaygın bir şekilde kullanımasına rağmen etkinlik ve fetal-neonatal güvenlik ile ilgili kaygılar (özellikle 26 haftadan önce kullanımında görülen sonuçların ilaç ile ilişkisi gösterilememesine rağmen) nedeniyle atosibanın FDA onayı bulunmamaktadır $(3,4)$. ORA'ların (çoğunlukla atosiban) metaanalizlerde gebelik süresinin uzaması ve neonatal sonuçlar açısından plasebo, $\beta$-mimetik ilaçlar veya kalsiyum kanal blokerleriyle kıyaslandığında herhangi bir üstünlüğü gösterilememiş olmakla beraber daha az maternal yan etki ile ilişkili olduğu bildirilmiştir (25).

Preterm Doğum Tedavisinde Kalsiyum Kanal Blokerleri (Nifedipin)

Myometrial aktivite sitoplazmik serbest kalsiyum ile doğrudan ilişkilidir ve azalan kalsiyum konsantrasyonları inhibe eder. Kalsiyum kanal blokerleri, çeşitli mekanizmalarla, hücre membran kanalları boyunca kalsiyum girişini inhibe eder. Farmakolojik etki muhtemel düz kas hücrelerine voltaj bağımlı kalsiyum kanallarının inhibisyonu ile ortaya çıkar, bu da hücre içi kalsiyumun azalmasına ve intraselüler depolardan kalsiyum salınımında azalmaya neden olur. Hipertansiyon tedavisi için geliştirilmiş olmalarına rağmen, preterm doğumu durdurucu özellikleri bulunmaktadır $(3,4)$. Tokolitik ajan olarak en yaygın kullanılan kalsiyum kanal blokeri nifedipindir. Nifedipin, oral uygulamadan birkaç dakika sonra plazmaya geçer, 15 ile 90 dakika arasında en yüksek konsantrasyonlara ulaşır ve 81 dakikalık bir yarı ömre sahiptir. Plasental transfer, oral nifedipin uygulamasından sonraki 2-3 saat içinde gerçekleşir. Tek bir dozun etki süresi annede 6 saate kadardır (3).

\section{Maternal etkileri}

Hipotansiyon ve baş ağrısı nifedipinin en yaygın yan etkileridir. Nifedipin öncesi sıvı tedavisiyle baş ağrısı (\%20), yüzde kızar- 
ma (flushing) (\%8), baş dönmesi ve bulantı (\%6) gibi maternal yan etki insidansı azaltılabilmektedir. Yan etkileri genellikle hafif olmakla beraber, sağlıkı bir genç kadında ikinci nifedipin dozundan 45 dakika sonra miyokard enfarktüsü olgusu bildirilmiştir. Kalp atım hızı ve kan basıncı üzerindeki etkileri nedeniyle $\beta$-agonist ile kalsiyum kanal blokerlerinin eşzamanlı veya ardışık kullanımı önerilmemektedir. Magnezyumun kalsiyum kanal blokerleri ile eşzamanlı uygulanması iskelet kası blokajına neden olabilir. Diğer tokolitiklerde olduğu gibi, maternal pulmoner ödem bildirilmiştir. Sonuç olarak kardiyovasküler yetmezliği olan hamile kadınlar ve/veya çoğul gebelik olgularında iv nikardipin ya da yüksek doz oral nifedipinden ( $\geq 150 \mathrm{mg} / \mathrm{gün}$ ) kaçınılmalıdır. Her durumda, uygulama sırasında kan basıncı monitorize edilmeli ve kardiyotokografi kaydedilmeli ve hastalara çiğnemekten kaçınmaları tavsiye edilmelidir $(3,26)$.

\section{Fetal etkileri}

Hayvan çalışmalarında fetal hipotansiyon bildirmiş olmasına rağmen preterm doğum için kalsiyum kanal blokerleri ile tedavi edilen kadınlarda fetal orta serebral arter, renal arter, duktus arteriyozus, umblikal arter veya maternal damarlardaki kan akım paterninde herhangi değişiklik gösterilememiştir (3).

\section{Tedavi protokolü}

Nifedipin tokolitik olarak genellikle 10-20 miligramlık (mg) başlangıç dozu ile oral yoldan verilir, kontraksiyonlar azalanana kadar her 3 ile 6 saatte bir tekrarlanır, ardından 8 ile 12 saatte bir 30 ya da 60 mg uzun etkili formülasyonları 48 saat boyunca steroid dozu tamamlanana kadar devam eder. Kısa etkili preparatlarda maternal ve fetal yan etkiler özellikle hipertansiyonu veya diğer kardiyovasküler bozuklukları olan kadınlarda daha olasıdır. Uzun etkili preparatların yan etkisi daha az olmakla beraber baş ağrısı ve hipotansiyon yinede görülür. Nifedipin total dozunun 60 mg'ı geçtiği olgularda olumsuz etkiler en yüksektir. Ancak etkinliği plasebo kontrollü çalışmalarla belirlenmemiş olması nedeniyle ideal doz rejimi net değildir (3).Yapılan çalışmalarda, kalsiyum kanal blokerleri, özellikle nifedipin, $\beta$-agonist ilaçlara göre daha güvenli ve daha etkili tokolitik ajan olarak gösterilmiştir (4). Lyell ve arkadaşlarının, 24-33 hafta arası 192 gebede yaptıkları randomize çalışmada magnezyum sülfat ve nifedipinin etki ve yan etki bakımından birbirlerine üstünlüğü bulunmamıştır (27). Başka bir randomize çalışmada, 24-33 hafta arasında preterm doğum yapan 145 kadına nifedipin veya atosiban tedavisi verilmiş, doğum eylemini geciktirmede anlamII fark bulunmamış, neonatal morbidite yönünden sonuçlar benzer bulunmuştur (28). Akut tokolizde maternal yan etkilerin ve etkinliğin kıyaslandığı tek merkez randomize kontrollü bir başka çalışmada ise nifedipin, magnezyum sülfat ve indometazin tedavilerinin birbirlerine üstünlüğü gösterilememiş, preterm eylem tedavisinde FDA onaylı tokolitik olmadığından, klinisyenlerin en az maternal ve neonatal yan etkilerle en iyi sonucu veren tokolitik tedaviyi tercih edebileceği sonucuna varımıştır (29). Fleady ve ark. 2511 hastanın ve 26 randomize çalışmanın dahil edildiği Cochrane analizinde etkinlik ve yan etki bakımından kalsiyum kanal blokerlerinin (özellikle nifedipin) preterm doğumu geciktirmede plasebo veya tedavi almayan gruba göre faydalı olduğu ve beta mimetiklere göre daha az fetal-maternal yan etkilerinin olduğu gösterilmiştir (30). Fakat bu konuda daha fazla randomize çift kör plasebo kontrollü çalışmalara intiyaç duyulmaktadır. Önemli olarak nifedipinin tokoliz amaçlı magnezyum ile kombinasyonu tehlikedir çünkü nifedipin, magnezyumun pulmoner ve kardiyak fonksiyonu etkileyebilecek nöromüsküler bloke edici etkilerini arttırı. Preterm doğum yapan 54 kadın üzerinde yapılan bir başka çalışmada ise, magnezyum sülfat ve nifedipin tedavisi alan hasta grubuyla herhangi bir tokolitik tedavi almayan hasta grubu arasında yarar, zarar yönünden herhangi bir fark bulunmamıştır (31).

\section{APOSTEL Çalışmaları}

Hollanda perinatal merkezlerinde, 24-34 hafta arasında preterm doğum semptomları olan, membranı intakt, kısa serviksli (10-30 mm arası) ve fetal fibronektin testi negatif olan kadınların dahil edildiği APOSTEL I çalışmasında, randomize olarak belirlenen 37 kadına nifedipin ( $80 \mathrm{mg} / \mathrm{gün}$ ) tokolizi uygulanmış, 36 kadın ise plasebo grup olarak belirlenmiştir. Nifedipin grubunda 3 kadında (\% 8.1), plasebo grubunda ise 1 kadında (\% 2.8) yedi gün içinde doğum gerçekleşmiştir. Doğumda ortalama gebelik haftası ise sırasıyla $37+0$ ve $38+2(p=0.008)$ şeklinde gösterilmiştir. Olumsuz sonuçlar (neonatal morbidite vs.) nifedipin grubunda 3 kadında (\% 8.1) tespit edilmiş, plasebo grubunda ise herhangi bir olumsuz sonuç gösterilememiştir. Sonuç olarak plasebo yaklaşımının, nifedipin tokolizinin gerisinde kalmadığı belirtilmiştir (32).

Hollanda'da nifedipin idame tokolizi, preterm doğum ve olumsuz perinatal sonuçların değerlendirildiği, 11 perinatal merkezin dahil olduğu çift kör, plasebo-kontrollü APOSTEL-II çalışmasında Haziran 2008-Şubat 2010 arası, 48 saat tokolizi tamamlanmış, kortikosteroid küründen sonra doğum yapmayan, 26-32 haftalık preterm doğum tehditi olan kadınlar çalışmaya dahil edilmiş, randomize olarak 201 kadına 12 gün boyunca oral nifedipin (80 $\mathrm{mg} / \mathrm{gün}$ ) verilmiş, 205 kadın plasebo grup olarak belirlenmiştir. Randomizasyon için ortalama gebelik haftası 29.2 olup, olumsuz perinatal sonuçlar (perinatal mortalite, kronik akciğer has- 
talığı, neonatal sepsis, intraventriküler hemoraji, periventriküler lökomalazi, nekrotizan enterokolit) açııından gruplar arasında anlamlı fark saptanmamıştır (nifedipin \%13.7, plasebo \%11.9, rölatif risk, 0,87; \%95 güvenlik indeksi). Sonuç olarak idame tokoliz (maintenance tocolysis) tedavisinin faydası gösterilememiştir (33).

Preterm doğum tehditinde nifedipin ve atosibanın etkinliği, güvenilirliği, maternal ve neonatal etkilerinin değerlendirildiği çok merkezli (Hollanda ve Belçika), randomize kontrollü APOSTEL III çalışmasında ise Temmuz 2011-2014 yıllarında 25-34 hafta arası preterm doğum tehditi olan toplam 510 kadından, 254 kadına oral nifedipin, 256 kadına iv atosiban tedavisi 48 saat uygulanmış, maternal, perinatal olumsuz sonuçlar bakımından iki grup arasında herhangi bir fark görülmemiş (nifedipin $\% 14$, atosiban $\% 15$, rölatif risk 2.2; $\% 95$ güvenlik indeksi) ve daha geniş katıımlı plasebo-kontrollü çalışmalara gereksinim duyulduğu vurgulanmıştır (34). Nifedipin ve atosibanın perinatal beyin hasarı üzerine etkisinin değerlendirildiği APOSTELIII çalışmasının ikincil analizinde ise 32.gebelik haftasından önce doğan çocuklarda beyin hasarı prevalansının yüksek olduğu, fakat nifedipine veya atosibana maruz kalan yenidoğanlarda beyin hasarı açısından anlamlı bir fark görülmediği gösterilmiştir (35). Yine maliyet etkinliğinin sorgulandığı çalışmada ise nifedipin tedavisinin, atosiban tedavisine göre daha düşük maliyetlerle sonuçlandığı bildirilmiştir (36).

Preterm doğum tehditinden 48 saat sonra doğum yapmamış kadınlarda servikal pesserin etkinliği ve perinatal sonuçların değerlendirileceği APOSTEL VI ve preterm doğum tehditinde atosiban ve plasebo gruplarında perinatal, neonatal sonuçların değerlendirileceği çok merkezli, randomize, çift kör, plasebo-kontrollü APOSTEL 8 çalışması ise halen devam etmektedir $(37,38)$.

Sonuç olarak nifedipin, maternal ve fetal yan etkilerinin nadir olması, oral uygulanabilirliği nedeniyle preterm doğum tehditinde medikal tedavide klinik pratikte ilk tercih edilen güvenli tokolitik ajanlardan birisidir ancak preterm doğum tedavisinde endikasyon dışı (off-label) kullanımaktadır. Bu konuda yapılacak yasal düzenlemeler preterm doğum yönetiminde klinisyenlere yardımcı olacaktır.

\section{KAYNAKLAR}

1. Practice Bulletin No. 171: Management of Preterm Labor. American College of Obstetricians and Gynecologists' Committee on Practice Bulletins-Obstetrics. Obstet Gynecol. 2016
Oct;128(4):e155-64.

doi:10.1097/AOG.0000000000001711. Review.

2. Blencowe $H$, Cousens $S$, Oestergaard MZ, Chou D, Moller AB, Narwal R, et al. National, regional, and worldwide estimates of preterm birth rates in the year 2010 with time trends since 1990 for selected countries: a systematic analysis and implications, Lancet 379:2162-2172, 2012.

3. Prevention and Management of Preterm Parturition. In: Resnik R, Lockwood CJ, Moore TR, Greene MF, Copel JA, Silver RM, et al. Creasy and Resnik's Maternal-Fetal Medicine: Principles and Practice, 8th Edition. Elsevier; 2019, 679-700.

4. Preterm Birth. In: Cunningham FG, Leveno JK, Bloom SL, Dashe SJ, Hoffman BL, Casey BM, et al. Williams Obstetrics, 25th Edition. McGraw-Hill Education; 2018, 804-828.

5. Matthews TJ, MacDorman MF, Thoma ME. Infant Mortality Statistics From the 2013 Period Linked Birth/Infant Death Data Set.Natl Vital Stat Rep. 2015 Aug 6;64(9):1-30.

6. Frey HA, Klebanoff MA. The epidemiology, etiology, and costs of preterm birth. Semin Fetal Neonatal Med. 2016 Apr;21(2):68-73. doi: 10.1016/j.siny.2015.12.011.

7. Younge N, Goldstein RF, Bann CM, Hintz SR, Patel RM, Smith PB, Bell EF, et al. Survival and neurodevelopmental outcomes among periviable infants. N Engl J Med. 2017 Feb 16;376(7):617-628. doi: 10.1056/NEJMoa1605566.

8. Eichenwald EC, Stark AR. Management and outcomes of very low birth weight. N Engl J Med. 2008 Apr 17;358(16):1700-11. doi: 10.1056/NEJMra0707601.

9. Goldenberg RL. The management of preterm labor. Obstet Gynecol. 2002 Nov;100(5 Pt 1):1020-37.

10. Walker KF, Thornton JG. Tocolysis and preterm labour. Lancet. 2016 May 21;387(10033):2068-2070. doi: 10.1016/ S0140-6736(16)00590-0

11. Preterm Labour and Birth.National Collaborating Centre for Women's and Children's Health (UK).London: National Institute for Health and Care Excellence (UK); 2015 Nov.

12. Lamont CD, Jørgensen JS, Lamont RF. The safety of tocolytics used for the inhibition of preterm labour. Review, Expert Opin Drug Saf. 2016 Sep;15(9):1163-73. doi: 10.1080/14740338.2016.1187128

13. Lewis R, Mercer BM, Salama M, Walsh MA, Sibai BM. Oral terbutaline after parenteral tocolysis: a randomized, double-blind, placebo-controlled trial. Am J Obstet Gynecol. 1996 Oct;175(4 Pt 1):834-7. 
14. Cotton DB, Strassner HT, Hill LM, Schifrin BS, Paul $\mathrm{RH}$. Comparison between magnesium sulfate, terbutaline and a placebo for inhibition of preterm labor: a randomized study. J Reprod Med. 1984 Feb;29(2):92-7.

15. Cox SM, Sherman ML, Leveno KJ. Randomized investigation of magnesium sulfate for prevention of preterm birth. Am J Obstet Gynecol. 1990 Sep;163(3):767-72.

16. Crowther CA, Brown J, McKinlay CJ, Middleton P. Magnesium sulphate for preventing preterm birth in threatened preterm labour. Cochrane Database Syst Rev. 2014 Aug 15;(8):CD001060. doi: 10.1002/14651858.CD001060.pub2. Review.

17. Food and Drug Administration: FDA drug safety communication: FDA recommends against prolonged use of magnesium sulfate to stop pre-term labor due to bone changes in exposed babies. May 30, 2013. Available at: http://www.fda. gov/drugs/drugsafety/ucm35333.htm. Accessed November 9, 2017

18. Morales WJ, Madhav H. Efficacy and safety of indomethacin compared with magnesium sulfate in the management of preterm labor: a randomized study. Am J Obstet Gynecol. 1993 Jul;169(1):97-102.

19. Berghella V, Rust OA, Althuisius SM. Short cervix on ultrasound: does indomethacin prevent preterm birth?Am J Obstet Gynecol. 2006 Sep;195(3):809-13.

20. Norton ME, Merrill J, Cooper BA, Kuller JA, Clyman RI. Neonatal complications after the administration of indomethacin for preterm labor. N Engl J Med. 1993 Nov 25;329(22):16027.

21. Amin SB, Sinkin RA, Glantz JC. Metaanalysis of the effect of antenatal indomethacin on neonatal outcomes. Am J Obstet Gynecol. 2007 Nov;197(5):486.e1-10.

22. Reinebrant HE, Pileggi-Castro $\mathrm{C}$, Romero $\mathrm{CL}$, Dos Santos RA, Kumar S, Souza JP, Flenady V. Cyclo-oxygenase (COX) inhibitors for treating preterm labour. Cochrane Database Syst Rev. 2015 Jun 5;(6):CD001992. doi: 10.1002/14651858. CD001992.pub3. Review.

23. Bisits A, Madsen G, Knox M, Gill A, Smith R, Yeo G, et al. The randomized nitric oxide tocolysis trial (RNOTT) for the treatment of preterm labor. Am J Obstet Gynecol. 2004 Sep;191(3):683-90.

24. Romero R, Sibai BM, Sanchez-Ramos L, Valenzuela GJ, Veille JC, Tabor B, et al. An oxytocin receptor antagonist (atosiban) in the treatment of preterm labor: a randomized, double-blind, placebo-controlled trial with tocolytic rescue. Am J Obstet Gynecol. 2000 May;182(5):1173-83.

25. Flenady V, Reinebrant HE, Liley HG, Tambimuttu EG, Papatsonis DN. Oxytocin receptor antagonists for inhibiting preterm labour. Cochrane Database Syst Rev. 2014 Jun 6;(6):CD004452. doi: 10.1002/14651858.CD004452.pub3. Review.

26. Oei SG. Calcium channel blockers for tocolysis: a review of their role and safety following reports of serious adverse events, Eur J Obstet Gynecol Reprod Biol. 2006 Jun 1;126(2):137-45. Epub 2006 Mar 29.

27. Lyell DJ, Pullen K, Campbell L, Ching S, Druzin ML, Chitkara $U$, et al. Magnesium sulfate compared with nifedipine for acute tocolysis of preterm labor: a randomized controlled trial. Obstet Gynecol. 2007 Jul;110(1):61-7.

28. Salim R, Garmi G, Nachum Z, Zafran N, Baram S, Shalev E. Nifedipine compared with atosiban for treating preterm labor: a randomized controlled trial. Obstet Gynecol. 2012 Dec;120(6):1323-31. doi: http://10.1097/AOG.0b013e$3182755 \mathrm{dff}$.

29. Klauser CK, Briery CM, Martin RW, Langston L, Magann EF, Morrison JC. A comparison of three tocolytics for preterm labor: a randomized clinical trial J Matern Fetal Neonatal Med. 2014 May;27(8):801-6. doi: 10.3109/14767058.2013.847416.

30. Flenady V, Wojcieszek AM, Papatsonis DN, Stock OM, Murray L, Jardine LA, Carbonne B. Calcium channel blockers for inhibiting preterm labour and birth. Cochrane Database Syst Rev. 2014 Jun 5;(6):CD002255. doi: 10.1002/14651858. CD002255.pub2.

31. How HY, Zafaranchi L, Stella CL, Recht K, Maxwell RA, Sibai BM, Spinnato JA. Tocolysis in women with preterm labor between 32 0/7 and 34 6/7 weeks of gestation: a randomized controlled pilot study. Am J Obstet Gynecol. 2006 Apr;194(4):976-81.

32. Vis JY, van Baaren GJ, Wilms FF, Oudijk MA, Kwee A, Porath MM et al.Randomized comparison of nifedipine and placebo in fibronectin-negative women with symptoms of preterm labor and a short cervix (APOSTEL-I Trial).Am J Perinatol. 2015 Apr;32(5):451-60. doi: 10.1055/s-0034-1390346.

33. Roos C, Spaanderman ME, Schuit E, Bloemenkamp $\mathrm{KW}$, Bolte $\mathrm{AC}$, Cornette $\mathrm{J}$ et al.Effect of maintenance tocolysis with nifedipine in threatened preterm labor on perinatal outcomes: a randomized controlled trial. JAMA. 2013 Jan 2;309(1):41-7. doi: 10.1001/jama.2012.153817. 
34. van Vliet EOG, Nijman TAJ, Schuit E, Heida KY, Opmeer BC, Kok M, et al. Nifedipine versus atosiban for threatened preterm birth (APOSTEL III): a multicentre, randomised controlled trial. Lancet. 2016 May 21;387(10033):2117-2124. doi: 10.1016/S0140-6736(16)00548-1.

35. Nijman TAJ, Goedhart MM, Naaktgeboren CN, de Haan TR, Vijlbrief DC, Mol BW, et al.Effect of nifedipine and atosiban on perinatal brain injury: secondary analysis of the APOSTEL-III trial.Ultrasound Obstet Gynecol. 2018 Jun;51(6):806-812. doi: 10.1002/uog.17512.

36. Nijman T, van Baaren GJ, van Vliet E, Kok M, Gyselaers W, Porath MM, et al.Cost effectiveness of nifedipine compared with atosiban in the treatment of threatened preterm birth (APOSTEL III trial).BJOG. 2019 Jun;126(7):875-883. doi: 10.1111/1471-0528.15625.
37. Hermans FJ, Schuit E, Opmeer BC, Oudijk MA, Bekker M, Woiski M, et al. Effectiveness of a cervical pessary for women who did not deliver $48 \mathrm{~h}$ after threatened preterm labor (Assessment of perinatal outcome after specific treatment in early labor: Apostel VI trial).BMC Pregnancy Childbirth. 2016 Jul 12;16(1):154. doi: 10.1186/s12884-016-0935-7.

38. Klumper J, Breebaart W, Roos C, Naaktgeboren CA, van der Post J, Bosmans J, et al.Study protocol for a randomised trial for atosiban versus placebo in threatened preterm birth: the APOSTEL 8 study.BMJ Open. 2019 Nov 26;9(11):e029101. doi: 10.1136/bmjopen-2019-029101. 